\title{
Phenology, Growth and Yield of Three Wheat (Triticum aestivum L.) Varieties as Affected by High Temperature Stress
}

\author{
Akbar HOSSAIN ${ }^{1 *}$, Jaime A. TEIXEIRA DA SILVA² \\ ${ }^{1}$ Wheat Research Center, Bangladesh Agricultural Research Institute, Nashipur, Dinajpur-5200, \\ Bangladesh;tanjimar2003@yahoo.com ("corresponding author) \\ ${ }^{2}$ Faculty of Agriculture and Graduate School of Agriculture, Kagawa University, Ikenobe, Miki-cho, 761-0795, Japan
}

\begin{abstract}
Wheat is the most important cereal in the world. However, due to an increasing trend of rising temperatures around the world, wheat may be exposed to greater thermal stress in the near future. Therefore, the identification and development of suitable wheat varieties is an important step to resolve this threat to production and to achieve high yield, even under high temperature stress. In this context, phenology, growth and yield of three elite varieties of wheat ('Gourab', 'BARI Gom-25' and 'BARI Gom-26') were evaluated under two sowing conditions: optimum (sown on November 15) and late heat stress condition (sown on December 27). All wheat varieties, when sown late, faced severe temperature stress that significantly affected phenology, growth and finally yield. Taking into consideration phenological variation, dry matter (fresh and dry weight) partitioning and grain yield, variety 'BARI Gom-26 performed better both in optimum and late heat stress, followed by 'BARI Gom-25'; 'Gourab' performed the least. On the basis of heat tolerance parameters [relative performance (RP) and heat susceptibility index (HSI)], 'BARI Gom-25' (RP-79\%; HSI-0.7) was the best performing variety followed by 'BARI Gom-26' (RP-74\%; HSI-0.9) under heat stress while 'Gourab’ (RP-61\%; HSI-1.3) was sensitive to heat.
\end{abstract}

Keywords: Bangladesh, spring wheat, yield and yield components

\section{Introduction}

Accounting for a fifth of humanity's food, wheat is second after rice as a source of calories in the diets of consumers in developing countries and is first as a source of protein (Braun et al., 2010). Wheat is an especially critical "staff of life" for the approximately 1.2 billion "wheat-dependent" to 2.5 billion "wheat-consuming" poor-men, women and children-who live on less than \$US 2/day (FAOSTAT, 2010). The International Food Policy Research Institute (IFPRI) projections indicate that the world demand for wheat will rise from 552 million tons in 1993 to 775 million tons by 2020, and 60\% in total by 2050 (Rosegrant et al., 1997; Rosegrant and Agcaoili, 2010). At the same time, climate change-induced temperature increases are likely to reduce wheat production in developing countries (where around $66 \%$ of all wheat is produced) by $20-30 \%$ (Esterling et al., 2007; Lobell et al., 2008; Rosegrant and Agcaoili, 2010). The IPCC (2007) noticed that global climate change (GCC) will have a major impact on crop production.

Regarding agriculture and food security, overall crop yield (wheat, maize and rice) could decrease in South Asia by up to $30 \%$ by the end of this century (compared with an increase as much as $20 \%$ in East and South East Asia) (Anonymous, 2012). In cereal production alone, the most conservative climate change projections suggest a mini- mum decline of 4-10\% across South Asia. In Bangladesh, rice production could fall by $8 \%$ and wheat production by $32 \%$ as early as 2050 (Anonymous, 2012). CIMMYTICARDA (2011) estimated that 20-30\% of wheat yield losses will occur by 2050 in developing countries as a result of an assumed temperature increase of $2-3^{\circ} \mathrm{C}$ on a global scale, but these yield losses will not be fully compensated by yield gains in high latitude regions, estimated at 1015\% (OECD-FAO, 2009).

The annual mean temperature of Bangladesh is $25.75^{\circ} \mathrm{C}$, which is expected to rise about $0.21^{\circ} \mathrm{C}$ by 2050 (Karmakar and Shrestha, 2000). The Organization for Economic Cooperation and Development (OECD) (2003) estimated a rise in temperature of $1.4^{\circ} \mathrm{C}$ by 2050 and $2.4^{\circ} \mathrm{C}$ by 2100 in Bangladesh. Islam (2009) estimated, from 34 meteorological climate sites in Bangladesh, that temperature increases over the past 100 years-for all Bangladesh-of $0.62^{\circ} \mathrm{C}$ (maximum) and $1.54^{\circ} \mathrm{C}$ (minimum) occurred in February. Poulton and Rawson (2011) reported that temperature in Bangladesh increased over the past two decades by $0.035^{\circ} \mathrm{C} /$ year. If this trend continues, temperatures will have increased $2.13^{\circ} \mathrm{C}$ more than 1990 levels by 2050 .

Substantial losses in rain-fed wheat are also anticipated: studies in India suggest that a $0.5^{\circ} \mathrm{C}$ rise in winter temperature would reduce wheat yield by 0.45 tones/ha while a similar rise in temperature of $>2.5^{\circ} \mathrm{C}$ would reduce non-irrigated wheat and rice farm revenue by $9-25 \%$ 
98

Tab. 1. Recent studies related to heat, drought and low temperature stress, primarily in wheat, from different countries around the world

\begin{tabular}{|c|c|c|c|}
\hline Country & Tested cultivars & Main research findings & Reference \\
\hline Denmark & Tested 2,255 Mexican wheat landraces & $\begin{array}{l}\text { Landraces were evaluated on the basis of canopy temperature depression } \\
\text { (LCC), and 1000-kernel weight. Three landrace cultivars with superior } \\
\text { and consistent LCC values were identified. These accessions are potentially } \\
\text { useful sources for improving heat tolerance in cultivated wheat. }\end{array}$ & Hede et al. (1999) \\
\hline Australia & Wheat 'Lyallpur' & $\begin{array}{l}\text { Despite favourable day/night temperature }\left(18 / 13^{\circ} \mathrm{C}\right) \text {, } \\
\text { drought reduced kernel dry weight at anthesis. }\end{array}$ & Wardlaw (2002) \\
\hline Sudan & Wheat 'Debira', 'El Nelein' and 'Donki' & $\begin{array}{l}\text { A 2-year field study in two regions showed that 'El Nelein' } \\
\text { performed best when sown late (air temp. } 17-24^{\circ} \mathrm{C} \text { ). }\end{array}$ & $\begin{array}{l}\text { Ahmed } \\
\text { et al. }(2003)\end{array}$ \\
\hline China & Spring wheat 'Ningchun 18' & $\begin{array}{l}\text { Soil water deficit both during the middle vegetative stage (jointing) and } \\
\text { the late reproductive stages (filling and maturity or filling) and no-soil- } \\
\text { water-deficit both during the late vegetative stage (booting) and the early } \\
\text { reproductive stage (heading) had the highest yield increase of } 25 \text { and } 14 \% \text {. }\end{array}$ & Zhang et al. (2006) \\
\hline Egypt & $\begin{array}{l}\text { Wheat cultivars 'Sakha8,' 'Sakha93', } \\
\text { 'Sakha61' 'Chinese spring' }\end{array}$ & $\begin{array}{l}\text { Based on drought susceptibility index 'Sakha8'and 'Sakha93' were found to } \\
\text { tolerant, and 'Sakha61' and 'Chinese spring' were found to susceptible. }\end{array}$ & $\begin{array}{l}\text { El-Fadly } \\
\text { et al. }(2007)\end{array}$ \\
\hline Turkey & $\begin{array}{l}20 \text { wheat cultivars ( } 16 \text { bread wheat, } \\
\text { Triticum aestivum; four durum } \\
\text { wheat, Triticum durum cultivars) }\end{array}$ & $\begin{array}{l}\text { Considering drought sensitivity indices over } 2 \text { years, the bread wheat } \\
\text { cultivars 'Yayla-305,' 'Gerek-79', 'Dagdas-94' and 'Bolal-2973' were } \\
\text { found to be more drought-tolerant than the other cultivars. }\end{array}$ & Bagci et al. (2007) \\
\hline Argentina & Wheat, barley and Triticale & $\begin{array}{l}\text { Wheat, barley and a triticale cultivar were evaluated in three } \\
\text { season under three thermal condition: control and two timing of } \\
\text { heating before anthesis and found stem elongation stage is most } \\
\text { sensitive to high temperature stress (yield reduction } 46 \% \text { ) }\end{array}$ & Ugarte et al. (2007) \\
\hline Hungary & Wheat 'GK-Elet' and 'Mv-Emese' & $\begin{array}{l}\text { Pot culture experiment in growth chamber indicated that 'Mv- } \\
\text { Emese'was good drought stress tolerance than GK-Elet }\end{array}$ & Lukacs et al. (2008) \\
\hline Bulgaria & $\begin{array}{l}\text { Two drought tolerant wheat } \\
\text { ('Katya' 'Zlatitza') and two } \\
\text { sensitive 'Sadovo' and 'Miziya') }\end{array}$ & $\begin{array}{l}\text { The obtained results showed that the drought tolerant varieties 'Katya' and } \\
\text { 'Zlatitza' had higher levels of these proteins, especially RBP and Clp proteases. }\end{array}$ & $\begin{array}{l}\text { Demirevska } \\
\text { et al. }(2008)\end{array}$ \\
\hline USA & Spring wheat variety 'Sinton' & $\begin{array}{l}\text { It was noticed that cool air temperature }\left(65^{\circ} \mathrm{F}\right) \text { lengthened the life } \\
\text { span and high temperature }\left(79^{\circ} \mathrm{F}\right) \text { shortened the life span }\end{array}$ & Frank et al. (2009) \\
\hline Portugal & $\begin{array}{l}\text { Four triticum genotypes ('Golia', } \\
\text { 'Sever', 'Acalou' and 'TE9306') }\end{array}$ & $\begin{array}{l}\text { It was concluded that under heat stress (day } / \text { night } 31 / 20^{\circ} \mathrm{C} \text { ), during } \\
\text { the grainfilling period, } \mathrm{Fe} \text { and } \mathrm{Mn} \text { helped to overcome stress. }\end{array}$ & Dias et al. (2009) \\
\hline Iran & $\begin{array}{l}\text { Wheat cultivars 'Azar-2', 'Sardari', } \\
\text { 'Frankia' and 'Trakia' }\end{array}$ & $\begin{array}{l}\text { It was observed that variety 'Frankia' performed better } \\
\text { in various level of terminal drought stress }\end{array}$ & Dalirie et al. (2010) \\
\hline Azerbaijan & $\begin{array}{l}\text { Two bread wheat ('Giymatli-2/17', } \\
\text { 'Azamatli-95') and two durum wheat } \\
\text { ('Garagylchyg-2', 'Barakatli-95') }\end{array}$ & $\begin{array}{l}\text { It was found that drought tolerant genotypes 'Azamatli-95' and } \\
\text { 'Barakatli-95' this decrease was less pronounced compared to genotypes } \\
\text { 'Garagylchyg-2' and 'Giymatli-2/17', which are sensitive to drought. }\end{array}$ & $\begin{array}{l}\text { Bayramov } \\
\text { et al. }(2010)\end{array}$ \\
\hline Pakistan & 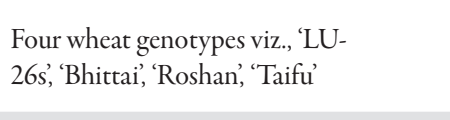 & $\begin{array}{l}\text { The genotypes 'LU-26s' was found to have best performance under } \\
\text { drought condition, with minimum decrease in the growth parameters } \\
\text { i.e., plant height, number of tillers and shoot dry weight. }\end{array}$ & Shirazi et al. (2010) \\
\hline Pakistan & $\begin{array}{l}\text { Five wheat cultivars ('TJ-83', } \\
\text { 'Imdad-2005', 'Abadgar-93', } \\
\text { 'Moomal-2000,' 'Mehran- 89') }\end{array}$ & $\begin{array}{l}\text { 'Moomal-2000' and 'Mehran- } 89^{\prime} \text { ' better performed under } \\
20-30^{\circ} \mathrm{C} \text { air temperature) heat stress. Cultivars 'TJ-83', } \\
\text { 'Imdad-2005' and 'Abadgar- } 93^{\prime} \text { ' were heat-sensitive }\end{array}$ & Buriro et al. (2011) \\
\hline $\begin{array}{c}\text { Saudi } \\
\text { Arabia }\end{array}$ & $\begin{array}{l}\text { Tested } 3 \text { cultivars ('KSU-105', } \\
\text { 'KSU-106 and 'Yecora Roja') }\end{array}$ & $\begin{array}{l}\text { 'KSU-105' performed better in late heat stress condition (temperature } \\
25-30^{\circ} \mathrm{C} \text { ). Cultivars 'KSU-106 and 'Yecora Roja' were heat-sensitive. }\end{array}$ & Refay (2011) \\
\hline Russia & Eight wheat genotypes & $\begin{array}{l}\text { Genotypes 'Zlata' showed sensitivity to low air temperature }\left(-3^{\circ} \mathrm{C}\right) \\
\text { and 'Ester' and Yubileinaya' showed tolerance to low temperature. }\end{array}$ & $\begin{array}{l}\text { Karmanenko } \\
\text { et al. (2011) }\end{array}$ \\
\hline Ethopia & $\begin{array}{l}18 \text { wheat cultivars 'B5-5B,' 'S-17B', and } \\
\text { 'WA-13,'Asassa, Bekelcha', 'Boohai, } \\
\text { Egersa,' 'Foka, Gerardo,' 'Ilani, T Kilinto,' } \\
\text { 'Obsa, Oda, 'Quamy', 'Tob-66 and } \\
\text { Yeror,',CDSS93Y107' 'CD94523' }\end{array}$ & $\begin{array}{l}\text { Water deficit significantly affected gas exchange and chlorophyll fluorescence } \\
\text { parameters. It reduced the net photosynthesis rate, transpiration rate and } \\
\text { stomatal conductance measured both at anthesis and grain-filling stages. }\end{array}$ & Bogale et al. (2011) \\
\hline India & $\begin{array}{l}\text { Wheat cultivars 'HD2851, 'HI8498', } \\
\text { 'HDR77', 'PBW343' and 'HD2936' }\end{array}$ & $\begin{array}{l}\text { Low temperature }\left(<18^{\circ}-20^{\circ} \mathrm{C} \text { air temperature }\right) \text { during reproductive } \\
\text { stage causes sterility of pollen grains. Cultivars, 'HD } 2851 \text {, } \\
\text { 'HI } 8498^{\prime} \text { and 'HDR77' were highly affected by low temperature } \\
\left(<15^{\circ} \mathrm{C}\right) \text {. Other two cultivars 'PBW } 343^{\prime} \text { and 'HD2936 were found } \\
\left.\text { low temperature (air temperature } 11.6 \text { to } 15^{\circ} \mathrm{C}\right) \text { tolerant. }\end{array}$ & $\begin{array}{l}\text { Chakrabarti } \\
\text { et al. }(2011)\end{array}$ \\
\hline $\begin{array}{l}\text { United } \\
\text { Kingdom }\end{array}$ & $\begin{array}{l}\text { Wheat 'Damani,' 'Gomal-8,' 'Hashim- } \\
\text { 8,'DN-73,'Zam-04'Dera-98' }\end{array}$ & Among these cultivars 'Hashim- 8 ' was found drought tolerant. & $\begin{array}{l}\text { Khakwani } \\
\text { et al. }(2011)\end{array}$ \\
\hline Jordan & Sixteen wheat cultivars & $\begin{array}{l}\text { Cultivars Waha-1, Omrabi-5, and Massara-1 genotypes performed } \\
\text { better in Mediterranean climate among genotypes studied. }\end{array}$ & Al-Karaki (2012) \\
\hline
\end{tabular}


(Anonymous, 2012). The Intergovernmental Panel on Climate Change (IPCC) estimates that by 2050, there will be changing rainfall patterns with increasing temperatures, flooding, droughts and salinity that would cause rice production to decline in Bangladesh by $8 \%$ and wheat by $32 \%$, against 1990 as the base year (CCC, 2009).

Several research findings noticed that temperature below $\left(<10^{\circ} \mathrm{C}\right)$ or above $\left(>25^{\circ} \mathrm{C}\right)$ the optimum $\left(12\right.$ to $\left.25^{\circ} \mathrm{C}\right)$ alter phenology, growth and development and finally reduce the yield of existing Bangladeshi wheat varieties (Hakim et al., 2012; Hossain et al., 2009, 2011, 2012a, 2012b, 2012c; Nahar et al., 2010; Rahman et al., 2009). Thus, heat is the greatest threat to food security in Bangladesh where wheat is the second most important food grain and where population is rapidly increasing (Indexmundi, 2011). The IPCC (2007), CIMMYT-ICARDA (2011), CGIAR (2009) and OECD (2003) reported that world wheat production will decrease due to global warming and developing countries, like Bangladesh, will be highly affected. Heat stress in wheat can be mitigated in two ways: heat management or the development of heat-tolerant cultivars. Breeding for cultivars that are tolerant to postanthesis high temperature stress is an effective strategy to overcome this problem. There is a concerted effort by researchers around the world to develop stress (heat and drought)-tolerant cultivars (Tab. 1). As a sub-set of this global effort, and in the light of future global warming forecasting for the country, Bangladeshi researchers, including our group, are also trying to develop heat-tolerant wheat varieties. Therefore, the study was conducted to identify heat-tolerant and -susceptible wheat varieties from existing varieties for future breeding programmes.

\section{Materials and methods}

\section{Experimental site}

The study was conducted at the experimental field of the Wheat Research Center (WRC), Dinajpur, Bangladesh during November, 2010 to April, 2011. The area falls under the Old Himalayan Piedmont Plain designated as Agro Ecological Zone 1 (FAO/UNDP, 1988). It is situated in northern part of Bangladesh and geographically, the area lies between $25^{\circ} 38^{\prime} \mathrm{N}, 88^{\circ} 41^{\prime} \mathrm{E}$ and $38.20 \mathrm{~m}$ above sea level. The soil is sandy-loam and strongly acidic $(\mathrm{pH}$ ranges from 4.5 to 5.5) (WRC, 2009).

Tab. 2. Characteristics of tested wheat varieties of Bangladesh

\begin{tabular}{|c|c|c|c|c|c|c|c|}
\hline Variety & $\begin{array}{c}\text { Duration } \\
\text { (Days) }\end{array}$ & $\begin{array}{c}\text { Yield } \\
\left(\mathrm{kg} \mathrm{ha}^{-1}\right)\end{array}$ & $\begin{array}{c}\text { Suitable area for } \\
\text { cultivation }\end{array}$ & $\begin{array}{l}\text { Year of } \\
\text { release }\end{array}$ & $\begin{array}{l}\text { Sowing } \\
\text { time }\end{array}$ & $\begin{array}{c}\text { Harvest } \\
\text { time }\end{array}$ & Major diseases and pests \\
\hline 'Gourab' & $102-108$ & $3500-4600$ & $\begin{array}{l}\text { All over the country } \\
\text { except in saline areas }\end{array}$ & 1998 & Nov.15-30 & Mar.-Apr. & $\begin{array}{l}\text { Tolerant to Bipolaris leaf blight } \\
\text { and resistant to leaf rust }\end{array}$ \\
\hline 'BARI Gom-25’ & $102-110$ & $3600-5000$ & $\begin{array}{l}\text { Suitable for southern region } \\
(8-10 \mathrm{dS} / \mathrm{m} \text { salinity level })\end{array}$ & 2010 & Nov.15-30 & Mar.-Apr. & $\begin{array}{l}\text { Highly tolerant to Bipolaris leaf blight } \\
\text { and resistant to leaf rust diseases. }\end{array}$ \\
\hline $\begin{array}{c}\text { 'BARI } \\
\text { Gom-26' }\end{array}$ & $104-110$ & $3500-5000$ & $\begin{array}{l}\text { Possible to grow throughout } \\
\text { the country except in areas } \\
\text { with salinity level }>6 \mathrm{dS} / \mathrm{m}\end{array}$ & 2010 & Nov. $15-30$ & Mar.-Apr. & $\begin{array}{l}\text { Tolerant to bipolaris leaf blight } \\
\text { and resistant to leaf rust diseases } \\
\text { (stem rust) race, Ug } 99\end{array}$ \\
\hline
\end{tabular}

Treatments and design

Three existing elite wheat varieties ('Gourab', 'BARI Gom-25' and 'BARI Gom-26') from WRC, Bangladesh were used as experimental materials. The characteristics of these varieties are presented in Tab. 2. Their performance was evaluated under two growing environments: the first was an optimum sowing (OS) environment (sown on 15 November) while the other was a post-anthesis heat stressed environment i.e., late sowing (LS) (sown on 27 December). The experiment was conducted in a randomized complete block design (RCBD) with a split plot arrangement and three replications. Sowing dates comprised the main plot and elite varieties of wheat comprised the subplot.

\section{Experimental procedure}

Before sowing, seeds were treated with Provax-200 WP, a seed-treated fungicide containing Carboxin and Thiram. Research conducted at the WRC (2009) indicated that Provax-200 WP is a perfect match for controlling fungi in Bangladesh soil, for achieving excellent seed germination and for protecting wheat cultivars from fungal attacks during the seedling stage. This fungicide is marketed by Hossain Enterprise CC Bangladesh Ltd., an agrochemical company engaged in crop protection and seed treatment, in association with Chemtura Corp., USA. Seeds were sown at $120 \mathrm{~kg} / \mathrm{ha}$. Unit plot size was $1.6 \times 4 \mathrm{~m} \mathrm{[} 4 \mathrm{~m}$ long 8 rows and row to row distance $20 \mathrm{~cm}$ (i.e., $9.6 \mathrm{~g}$ seeds/ row)]. Fertilizer was applied at doses recommended by the WRC: $100-27-40-20-1 \mathrm{~kg} / \mathrm{ha}$ of $\mathrm{N}$ (nitrogen), P (phosphorus), $\mathrm{K}$ (potassium), S (sulfur), and B (boron). Twothirds of $\mathrm{N}$ and a full amount of the other fertilizers were applied as a basal amount during final land preparation. The remaining $\mathrm{N}$ fertilizer was applied immediately after the first irrigation [21 days after sowing (DAS)]. Second and third irrigations were applied at booting (47 DAS) and grain-filling (78 DAS) stages. Intercultural operations were done properly according to treatments.

\section{Data collection and their procedure}

The crop was harvested plot-wise at full maturity according to treatments. Sample plants were harvested separately from an area of $3 \times 1.2 \mathrm{~m}$ (i.e., $3 \mathrm{~m}$ long middle 6 rows), avoiding border effects. The harvested sample crop of each plot was bundled separately, tagged and taken to a threshing floor. The bundles were thoroughly dried un- 
100

der bright sunshine until fully dried, then weighed and threshed.

Phenological data on days to germination (DG), booting (DB), first visible awn (DFAV), heading (DH), anthesis (DA), physiological maturity (DPM) and harvest maturity (DHM); biomass data on 30-culm fresh weight (FW) and dry weight (g) (DW), and yield (GY) data on 30-culm grain weight $(\mathrm{g})$ were recorded. To obtain the actual yield of all varieties, grain yield weight was adjusted at $12 \%$ moisture by the following equation (Hellevang, 1995):

$\mathrm{Y}\left(\mathrm{M}_{2}\right)=\frac{100-\mathrm{M}_{1}}{100-\mathrm{M}_{2}} \times \mathrm{Y}\left(\mathrm{M}_{1}\right)$

Where, $\mathrm{Y}\left(\mathrm{M}_{2}\right)=$ weight of grain at expected moisture percentage (generally $12 \%$ for wheat); $Y\left(M_{1}\right)=$ weight of grain at present moisture percentage; $M_{1}=$ present moisture percentage; $\mathrm{M}_{2}$ = expected moisture percentage.

Heat tolerant data of relative performance (\%) and heat susceptibility index were calculated by following equations. Relative performance (RP\%) for yield was calculated as described by Asana and Williams (1965) and was expressed as a percentage:

R P $(\%)=\frac{\text { Stress performance }}{\text { Optimum performance }} \times 100$

Heat susceptibility index (HSI) was calculated for each genotype according to the formula of Fischer and Maurer (1978):

$$
\mathrm{HSI}=\frac{1-\frac{\mathrm{Y}}{\mathrm{Y}_{\mathrm{p}}}}{1-\frac{\mathrm{X}}{\mathrm{X}_{\mathrm{p}}}}
$$

Where

$\mathrm{Y}=$ mean grain yield of a genotype under a stress environment

$\mathrm{Y}_{\mathrm{p}}=$ mean yield of the same genotype under a stressfree environment

$\mathrm{X}=$ mean $\mathrm{Y}$ of all genotypes

$\mathrm{X}_{\mathrm{p}}=$ mean $\mathrm{Y}$ of all genotypes

If ${ }^{p} \mathrm{HSI}<0.5^{\mathrm{p}}$, the crop is highly tolerant to high temperature stress, if HSI $>0.5<1.0$, it is moderately tolerant, and if HSI > 1.0, it is susceptible to high temperature stress.

Temperature data was recorded regularly by $\mathrm{HOBO}$ U12 Family of Data Loggers (MicroDAQ.com) at the meteorological station, WRC, Dinajpur, Bangladesh and is presented in Fig. 1.

Data was analyzed using MSTAT-C (Russell, 1994). Treatment means were compared for significance by the least significant difference (LSD) test at $p=0.05$.

\section{Results and discussion}

Temperature is a modifying factor in all stages of wheat development including germination, tillering, booting, ear emergence, anthesis and maturity since it can influence the rate of water supply and other substrates necessary for growth, but varies with plant species, variety and phenological stages (Wahid et al., 2007). Under high temperature, the crop completes its life cycle much faster than under normal temperature conditions (Fischer, 1985; Hakim et al., 2012; Hossain et al., 2009, 2011, 2012a, 2012b, 2012c; Nahar et al., 2010; Rahman et al., 2009). Delayed planting in a sub-tropical region such as Pakistan, India, Bangladesh, etc. reduced plant height, $\mathrm{DH}$, days to maturity and the duration of grain filling and ultimately reduced yield and yield components (Din and Singh, 2005; Mahboob et al., 2005).

\section{Days to germination}

Low temperature is one of the most important environmental parameters of late-sown wheat in sub-tropical environments. Chakrabarti et al. (2011) conducted a field experiment in India and found that air temperature $<15^{\circ} \mathrm{C}$ was not suitable for the growth and development (germination, seedling stand establishment and tillering) of spring wheat. Timmermans et al. (2007) reported that seedling emergence and establishment in Solanum sisymbriffolium, when planted late, were negatively affected by low temperature during germination. At the time of our present research, the maximum temperature during the germination period was $>26$ to $28^{\circ} \mathrm{C}$, sometimes nearing $30^{\circ} \mathrm{C}$, while the minimum temperature was between 12 and $13^{\circ} \mathrm{C}$, in OS. However, at $\mathrm{LS}$, the average maximum and minimum temperatures were near 23 and $10^{\circ} \mathrm{C}$, and

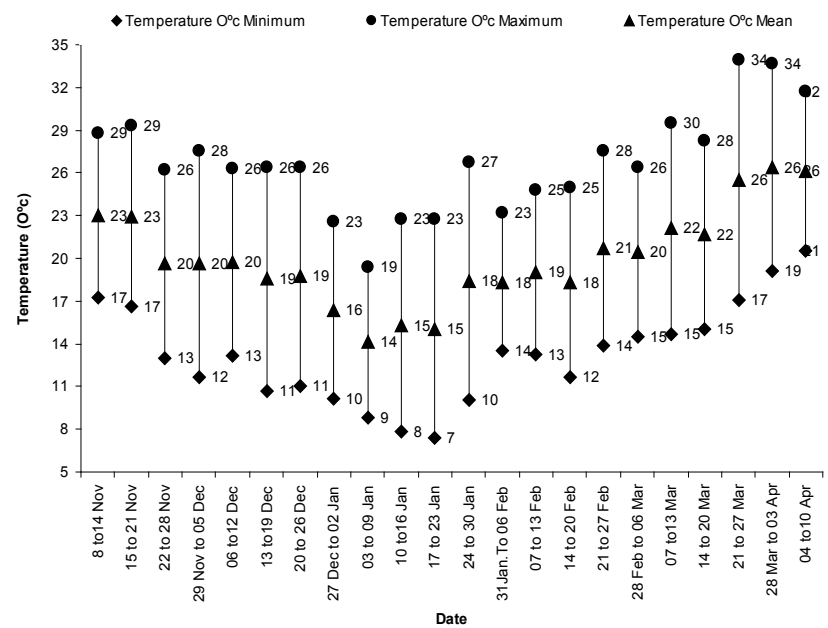

Fig. 1. Temperature $\left({ }^{\circ} \mathrm{C}\right)$ during the wheat growing period. Source: Meteorological Station, Wheat Research Centre, Nashipur, Dinajpur, Bangladesh 


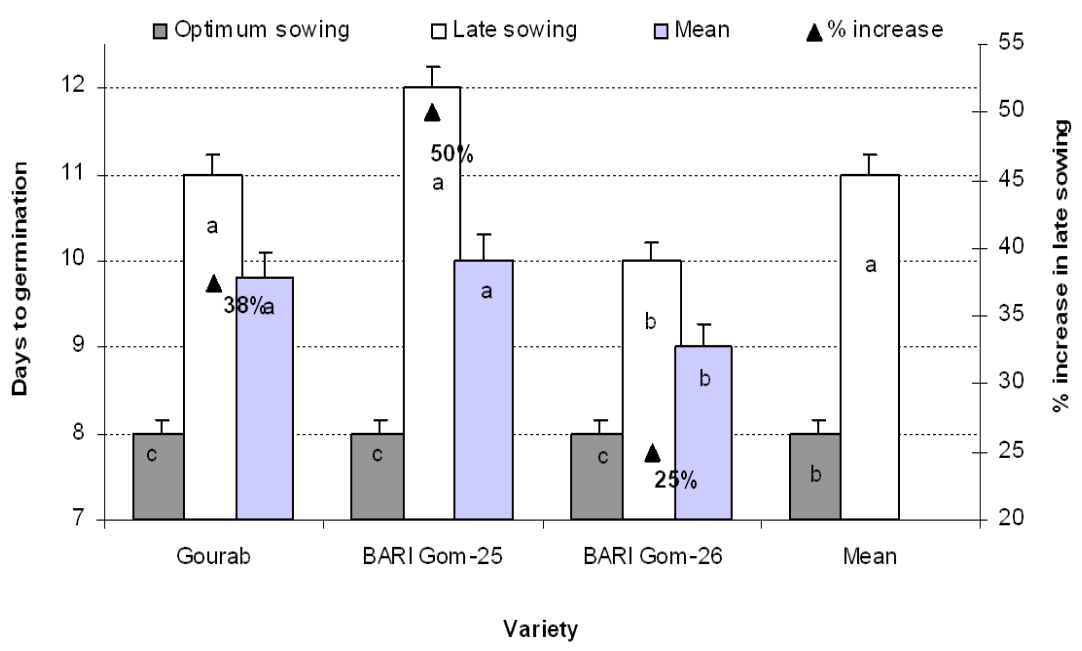

Fig. 2. Days passed to germination of 3 wheat varieties sown under optimum and very late conditions. Mean $( \pm S D)$ was calculated from three replicates for each treatment. Bars with different letters are significantly different at $p \leq 0.05$ (LSD test)

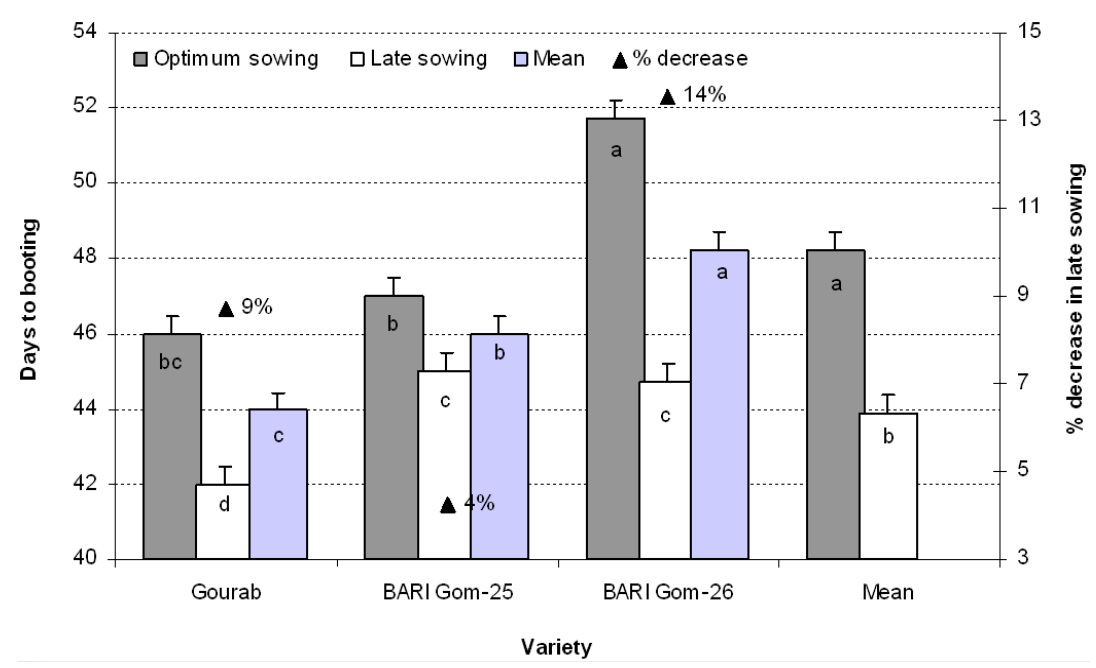

Fig. 3. Days passed to booting of 3 wheat varieties when sown under optimum and very late conditions. Mean $( \pm S D)$ was calculated from three replicates for each treatment. Bars with different letters are significantly different at $p \leq 0.05$ (LSD test)

sometimes minimum and maximum temperature ranged between $8-9^{\circ} \mathrm{C}$ and $20-19^{\circ} \mathrm{C}$, respectively (Fig. 1). The required DG was earlier when temperature was higher (in OS) but germination was later in LS due to low temperatures (Fig. 2). This claim is supported by Fig. 1 and previous results reported by Hossain et al. $(2011,2012$ c), who conducted a field experiment in Bangladesh and noted that low temperature $\left(<10^{\circ} \mathrm{C}\right)$ at the germination stage delayed the time taken for grain to germinate. Significant differences in DG were found among the three varieties with respect to OS and LS. Among them, 'BARI Gom-25' took more time to germinate in LS than other varieties, closely followed by 'Gourab'. On the other hand, 'BARI Gom-26' took least time to germinate. In OS, all three varieties took statistically similar time to germinate (Fig. 2). In our study, the required DG increased by $50 \%$ in 'BARI Gom-25' followed by $38 \%$ in 'Gourab' and $25 \%$ in 'BARI Gom-26' in LS, due to low temperature stress.

\section{Days to booting}

Reproductive phases like booting, fertilization and gametogenesis (8-9 days before anthesis) are most sensitive to high temperature in various plants (Foolad, 2005; Tarchoun et al., 2012), as also observed with our present research findings, which noted that $\mathrm{DB}$ of the three evaluated varieties were significantly different in OS and LS. Among the varieties 'BARI Gom-26' took the most time for booting while 'Gourab' took the least time under both OS and LS (Fig. 3). In LS, required DB was reduced the most, by $14 \%$ in 'BARI Gom-26' and the least in 'BARI Gom-25' by 4\%. Hakim et al. (2012) evaluated 20 wheat cultivars in same agro-climatological conditions and noticed that the life span of all wheat cultivars were reduced in $\mathrm{LS}$ due to high temperature stress $\left(>25^{\circ} \mathrm{C}\right)$ at the reproductive stage. 


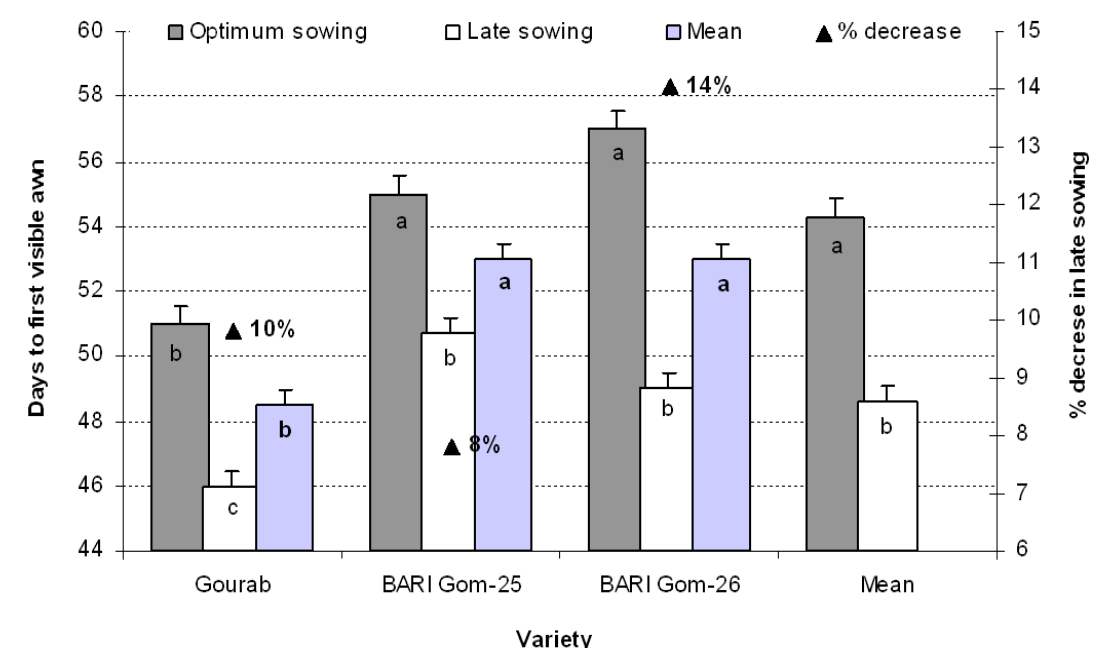

Fig. 4. Days passed to the first visible awn of 3 wheat varieties when sown under optimum and very late conditions. Mean $( \pm S D)$ was calculated from three replicates for each treatment. Bars with different letters are significantly different at $p \leq 0.05$ (LSD test)

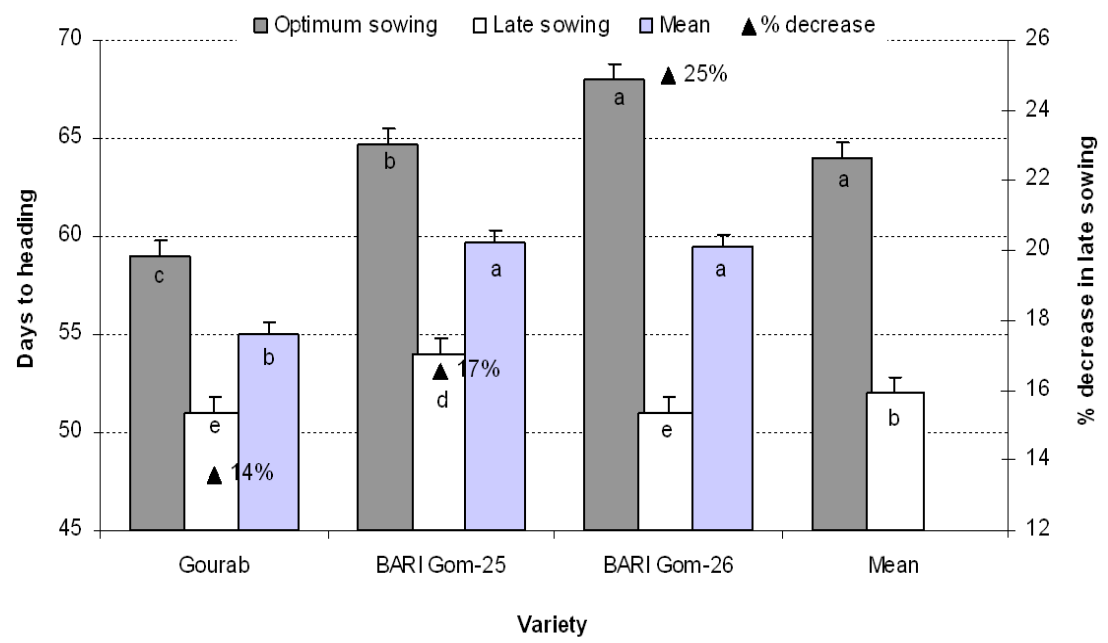

Fig. 5. Days passed to heading of 3 wheat varieties when sown under optimum and very late conditions. Mean $( \pm S D)$ was calculated from three replicates for each treatment. Bars with different letters are significantly different at $p \leq 0.05$ (LSD test)

\section{Days to first visible awn}

Growth chamber and greenhouse studies suggested that high temperature is most deleterious when flowers are first visible and sensitivity continues for 10-15 days (Foolad, 2005). In our present findings, due to heat stress in LS, all three evaluated varieties had a shorter life span than OS, which ultimately affected final GY (Fig. 1, 4 and 10). Both in OS and LS, 'BARI Gom-26' and 'BARI Gom-25' took more time than 'Gourab' to reach the first visible awn. Under high temperature stress, the required DFAV was reduced by $14 \%$ in 'BARI Gom-26' and by $8 \%$ in 'BARI Gom-25'. Nahar et al. (2010) also observed a decrease in the life span of wheat varieties in LS but not in OS, due to high temperature stress; in their study, maximum temperature at vegetative and reproduction stages were 25 to $27^{\circ} \mathrm{C}$ and 30 to $32^{\circ} \mathrm{C}$, respectively.

\section{Days to ear emergence/heading}

The developmental stage in which the spike or ear partially or fully appears to emerge from its enclosing sheath is also called ear emergence or heading (Acevedo et al., 2002). However, the time taken for the spike or ear to emergence from the enclosing sheath is entirely dependent on growth conditions. In our study, the three varieties evaluated needed most time for heading in OS and less time in heat stress (LS) (Fig. 5). Among them, 'BARI Gom-26' and 'BARI Gom-25' took statistically similar and longest time while 'Gourab' required the least time to reach heading due to heat stress in LS (Fig. 1, 5). Due to heat stress, the reduction in required $\mathrm{DH}$ was highest in 'BARI Gom-26' (25\% reduction) and lowest in 'Gourab' (14\% reduction). Hossain et al. (2011, 2012b, 2012c), Nahar et al. (2010), Rahman et al. (2009) and Ubaidullah et al. 


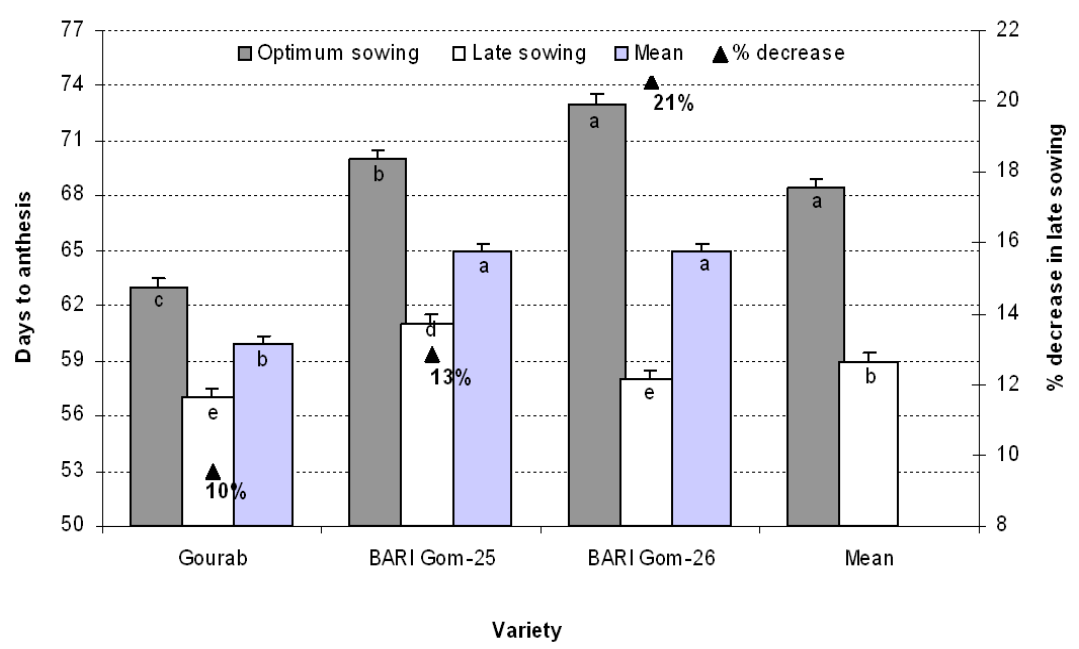

Fig. 6. Days passed to anthesis of 3 wheat varieties when sown under optimum and very late conditions. Mean $( \pm S D)$ was calculated from three replicates for each treatment. Bars with different letters are significantly different at $p \leq 0.05$ (LSD test)

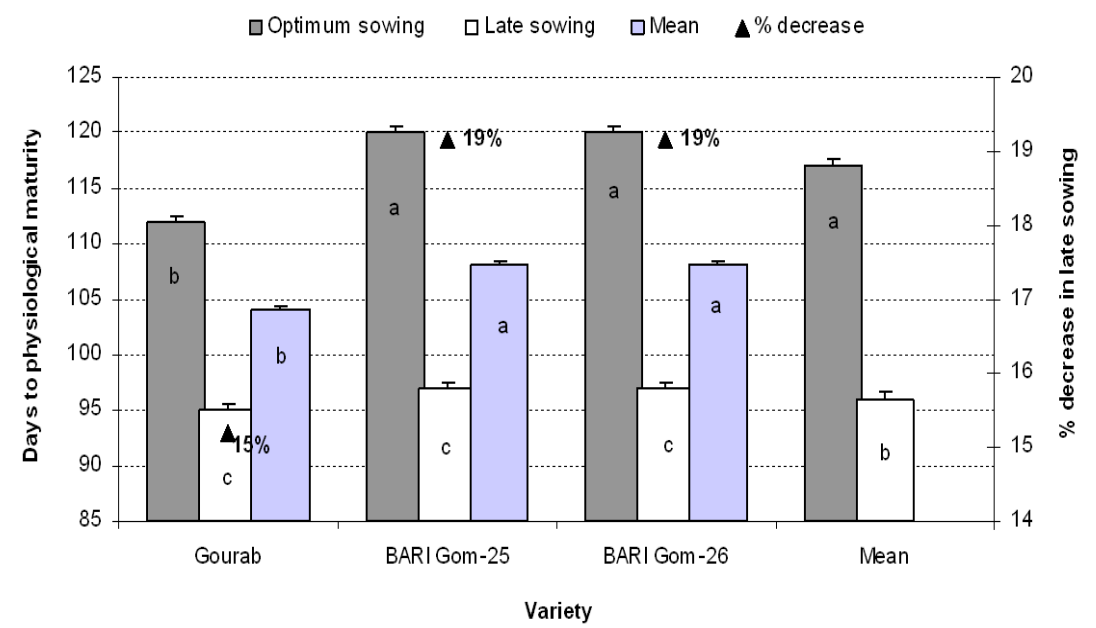

Fig. 7. Days passed to physical maturity of 3 wheat varieties when sown under optimum and very late conditions. Mean $( \pm S D)$ was calculated from three replicates for each treatment. Bars with different letters are significantly different at $p \leq 0.05$ (LSD test)

(2006) also observed that delayed sowing in wheat shortened the duration of each developmental phase due to a rise in temperature. They also reported up to 23 days difference between OS and LS for heading. Al-Karaki (2012), investigating 16 wheat cultivars in a Mediterranean climate, showed long pre-heading periods, followed by short periods and high rates of grain filling to avoid terminal drought and high temperature stress $\left(25-31^{\circ} \mathrm{C}\right)$. Among them, 'Waha-1', 'Omrabi-5' and 'Massaa-1' were tolerant to stress (drought and high temperature).

\section{Days to anthesis/flowering}

The main developmental stage when yellow anthers are clearly visible on spikes is termed anthesis or flowering (Acevedo et al., 2002). In the present experiment, it was found that all three varieties showed a different duration to reach anthesis, both in LS and OS, due to temperature differences. 'BARI Gom-26' and 'BARI Gom-26' took more but statistically similar time both in LS and OS while 'Gourab' took less time to reach anthesis. In LS, all three varieties showed a reduced life span to complete anthesis due to heat stress. Among them, 'BARI Gom-26' took less time ( $21 \%$ reduction) than 'Gourab' ( $10 \%$ reduction) to reach anthesis (Fig. 6). Hakim et al. (2012) also noticed that 20 wheat cultivars took 14 to $19 \%$ less time in LS than OS to reach days to flowering, due to high temperature stress $\left(>25^{\circ} \mathrm{C}\right)$.

\section{Days to physiological maturity}

The DPM of wheat cultivars varies due to inherent differences between cultivars (Shahzad et al., 2007), but is influenced by different environmental conditions (Spink et al., 1993). They also observed that delayed sowing shortens the duration of each developmental phase due to 


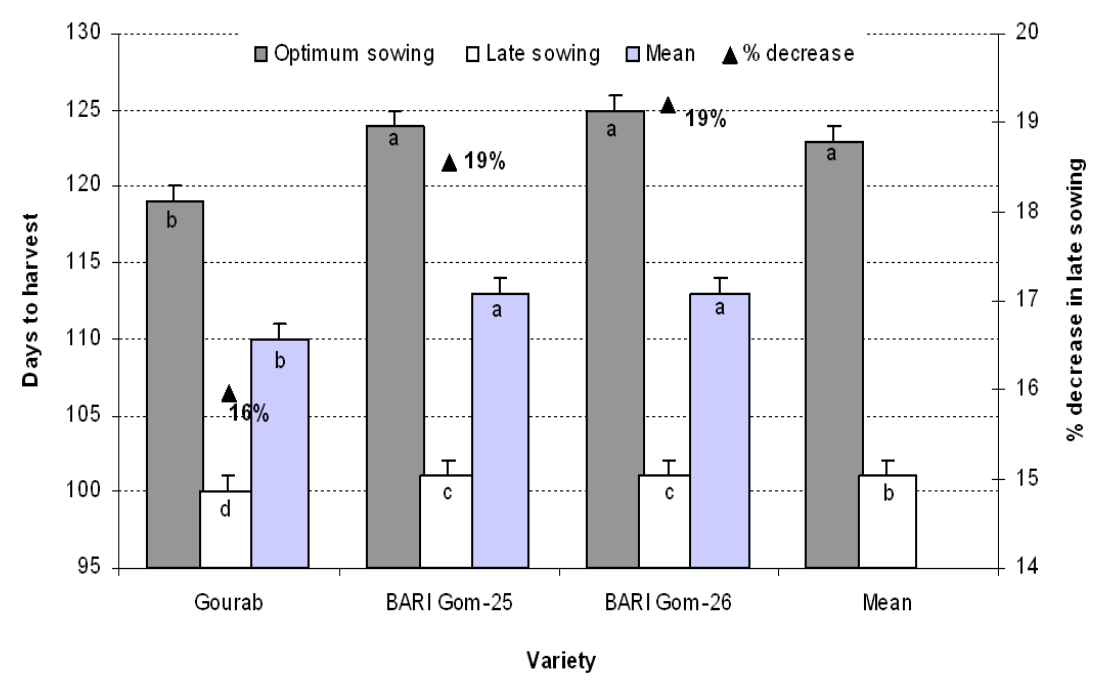

Fig. 8. Days passed to harvest of 3 wheat varieties when sown under optimum and very late conditions. Mean $( \pm S D)$ was calculated from three replicates for each treatment. Bars with different letters are significantly different at $p \leq 0.05$ (LSD test)

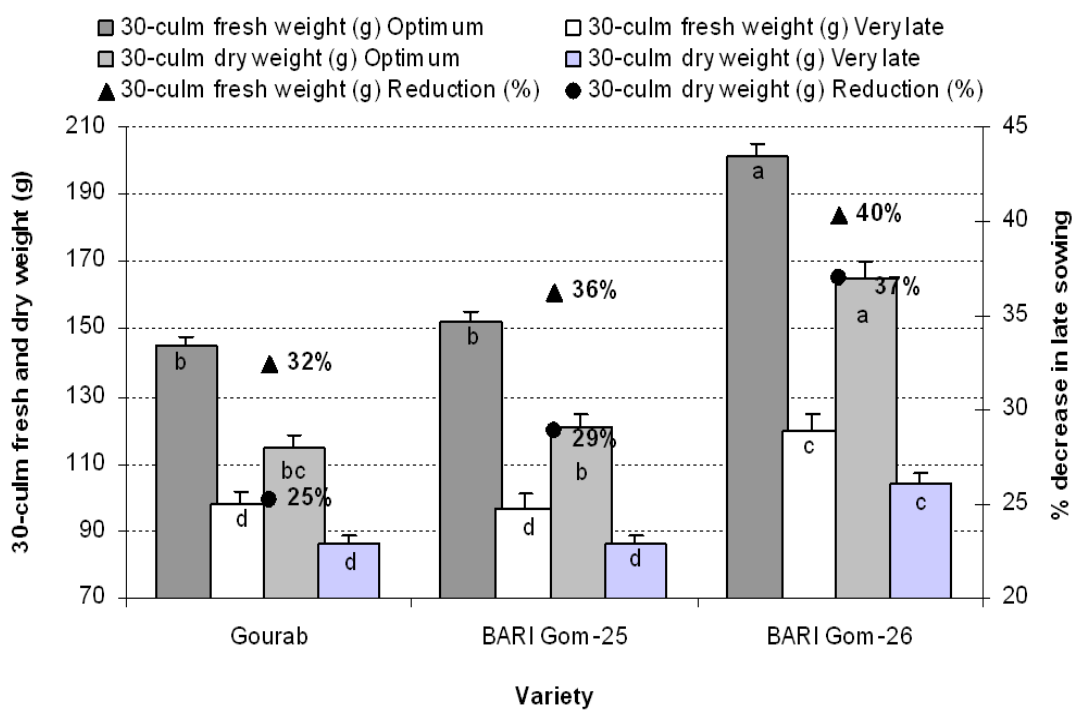

Fig. 9. 30-culm fresh and dry weights of 3 wheat varieties, sown under optimum and very late conditions. Mean $( \pm S D)$ was calculated from three replicates for each treatment. Bars with different letters are significantly different at $p \leq 0.05$ (LSD test)

a rise in temperature. This observation is similar to that of our present research findings. In our research, DPM of all three varieties decreased significantly from OS to LS (Fig. 7). Among the 3 tested varieties, 'BARI Gom-26' and 'BARI Gom-25' were statistically similar but took the most time to reach PM in both OS and LS while 'Gourab' needed fewer days. However, in LS, all 3 varieties had a reduced life span from germination to physiological maturity. Among them, 'BARI Gom-26' and 'BARI Gom-25' needed 19\% less time to reach PM than 'Gourab' which needed $15 \%$ less time as a result of heat stress during this period of LS (Fig. 7). Hakim et al. (2012); Hossain et al. (2011, 2012b, c) and Rahman et al. (2009) also observed that LS shortened the duration of each development phase due to high temperature stress at the reproductive stage.

\section{Days to harvest maturity}

Environmental factors affect the number of days required to reach or achieve different growth stages in wheat, but that this varies with genotype due to their different genetic makeup (Araus et al., 2007). In the present study all 3 varieties matured earlier in LS than in OS. Among them, 'Gourab' matured earlier both in OS and LS while the two other varieties needed statistically more time to mature, 'Gourab' finally yielding lower GY (Fig. 8, 10). The temperature during the grain-filling or grain-maturing period was near $22^{\circ} \mathrm{C}$ in $\mathrm{OS}$ and $>30^{\circ} \mathrm{C}$ in LS, which ultimately forced the life span to become complete (Fig. 1). There is also a similarity between this result and that of a 2-year study by Ubaidullah et al. (2006) in which heading, grain filling and grain maturity were 23, 3 and 29 days earlier 


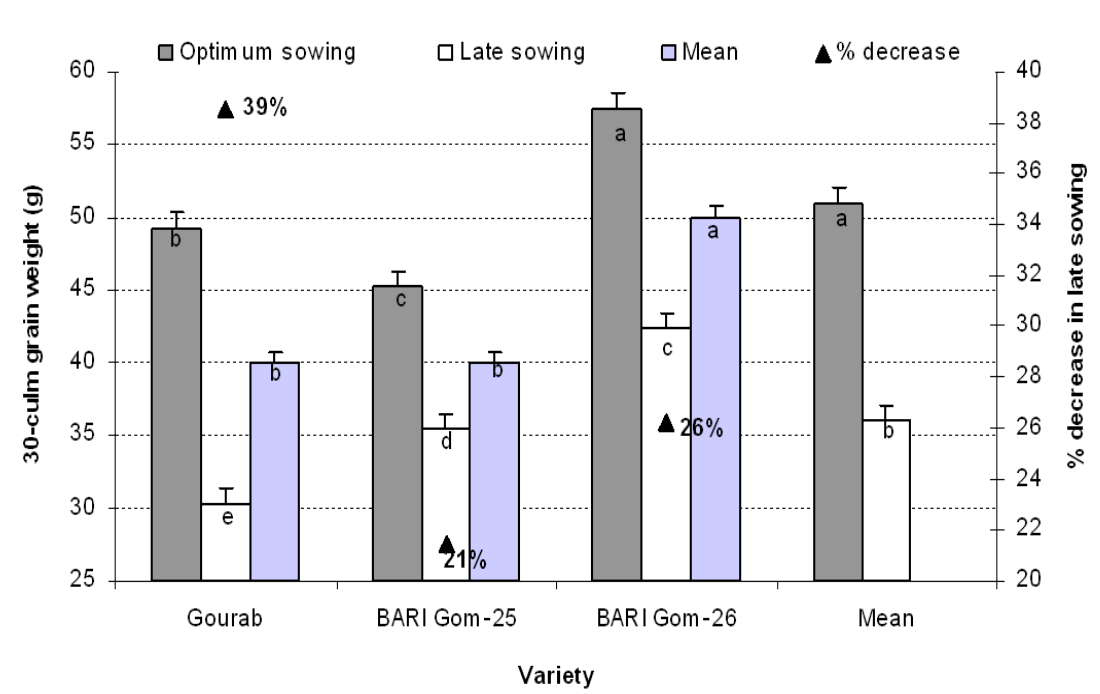

Fig. 10. Grain yield of 3 wheat varieties when sown under optimum and very late conditions. Mean $( \pm S D)$ was calculated from three replicates for each treatment. Bars with different letters are significantly different at $p \leq 0.05$ (LSD test)

when wheat was sown late than when sown normally due to heat stress during LS. Due to heat stress in LS, 19\% less time was required to reach DHM in 'BARI Gom-26' and 'BARI Gom-25' and 16\% less time in 'Gourab'. Nahar et al. (2010) also observed a reduction in the number of required days to maturation in LS due to high temperature stress.

\section{Fresh weight and dry weight}

Under optimal conditions, 80 to $90 \%$ of the carbohydrates translocated to the wheat grain are assimilates from current photosynthesis and 10 to $20 \%$ from the plant's reserve (Spiertz and Vos, 1985). However, under stress conditions such as drought and high temperature, crops do not translocate carbohydrates to grain because in this situation the crop basically survives without production (Hall, 2001) or resource allocation (Martiniello and Teixeira da Silva, 2011). Hasan and Ahmed (2005) conducted a field experiment in Bangladesh (sub-tropical climate) and found that post-anthesis heat stress $\left(>26^{\circ} \mathrm{C}\right)$ reduced maximum dry matter accumulation due to a reduction in wheat kernel dry matter, mirroring our experimental results. In LS, all 3 tested varieties were highly affected by heat stress, expressed as a reduction in dry matter (FW and DW) and GY (Fig. 9; 10). For these parameters, 'BARI Gom-26' performed better, followed by 'BARI Gom-25' while 'Gourab' performed worst in LS. Due to heat stress in LS, the highest reduction in FW and DW was 40 and $37 \%$ in 'BARI Gom-26', followed by 'BARI Gom-25' (29 and 36\%) and the least reduction was 25 and 32\% in 'Gourab' (Fig. 9). Ahamed et al. (2010) evaluated 5 existing wheat varieties of Bangladesh under two growing conditions (optimum and late) and showed that dry matter partitioning and production in all 5 varieties was affected at LS due to heat stress $\left(30\right.$ to $\left.32^{\circ} \mathrm{C}\right)$, resulting in reduced GY.

\section{Grain yield}

Sowing time is the most important for temperaturesensitive cereals such as wheat, barley, sorghum, etc., but the time of planting and their effectiveness on a plant varies from region to region. In Kansas, USA, planting during OS encourages tillering during fall and spring, reduces competition among tillers, and promotes a high harvest index (HI). Early planting causes excessive tillering, increases competition, and leads to a low HI. LS wheat decreases tillering during fall and spring and causes tillers that develop during spring to be small with a low HI (Thiry et al., 2002). In Bangladesh, early wheat faces high temperature stress at the vegetative stage and LS wheat is affected at two stages: germination by low temperature stress $\left(<10^{\circ} \mathrm{C}\right)$ and at the reproductive stage by high temperature $\left(>25^{\circ} \mathrm{C}\right.$ ), which ultimately affects GY (Hossain $e t$ al., 2011;2012c). Every $1^{\circ} \mathrm{C}$ rise in temperature above the optimum $\left(15^{\circ} \mathrm{C}\right)$ reduces yield by $3-4 \%$ per spike (Wardlaw et al., 1989a, 1989b).

In our present study, all 3 varieties were highly affected by heat stress in LS than in OS, which finally drastically reduced GY. Among the 3 varieties, 'BARI Gom-26' produced statistically highest GY both in OS and LS, followed by 'BARI Gom-25' while 'Gourab' produced least GY. However, the rate of reduction varied from genotype to genotype. Among 3 varieties, 'Gourab' (39\% yield reduction in LS) was highly affected by high temperature stress in LS than 'BARI Gom-25' (21\% yield reduction in LS) and 'BARI Gom-26' (26\% yield reduction in LS) (Fig. 10). In our research, fluctuations in weather conditions (Fig. 1) were reflected in phenology, crop growth and development (Fig. 2 to 9) and ultimately GY (Fig. 10), which is common to several crops (Martiniello and Teixeira da Silva, 2011). Previous research findings also indicated that high temperature significantly decreased all traits, especially GY (by $46.63 \%$ ), 1000-kernel weight (by $20.61 \%$ ) 


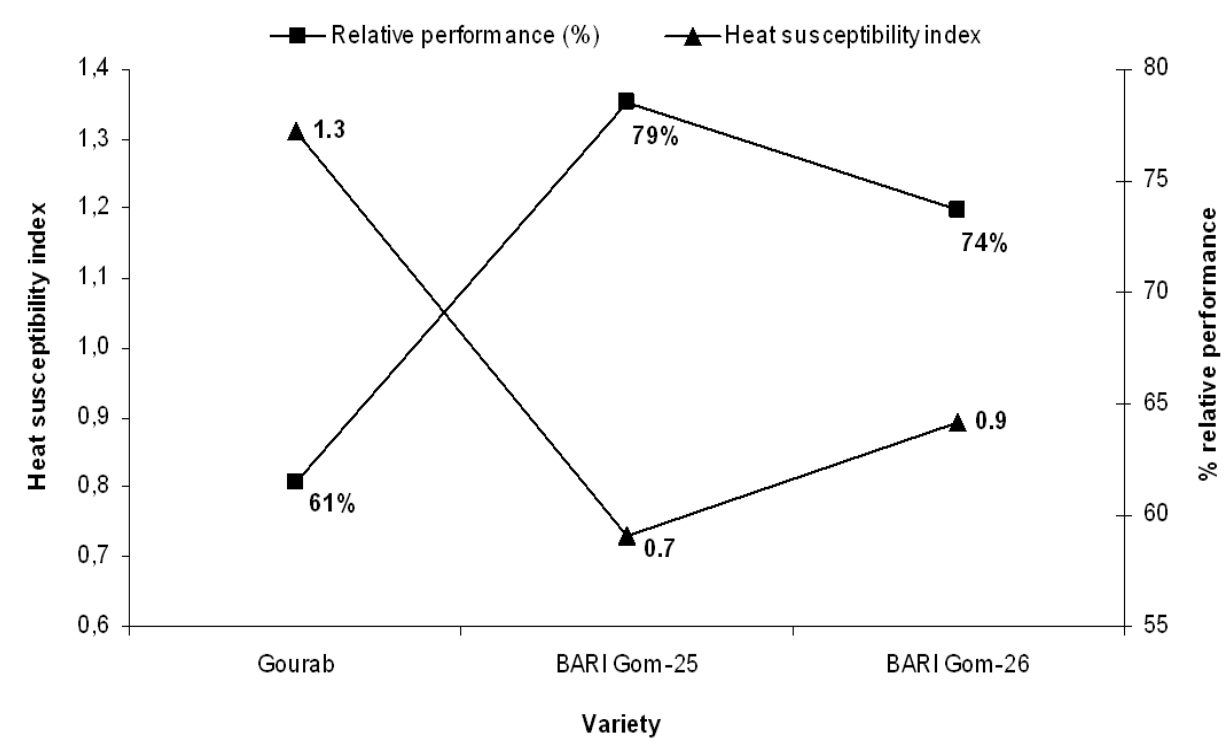

Fig. 11. Relative performance (\%) and heat susceptibility index of 3 wheat varieties in very late heat stress condition, as compared with optimum sowing

and grain filling duration (by 20.42\%) under high temperature stress $\left(>25\right.$ to $30^{\circ} \mathrm{C}$ ) (Modarresi et al., 2010).

\section{Relative yield performance and heat susceptibility index}

The performance of different genotypes under stress may be observed by calculating RP\% (Asana and Williams, 1965) and HSI (Fischer and Maurer, 1978). Rahman et al. (2009) also reported genotypic variation in RP\% of sensitive and tolerant genotypes, and a higher RP\% indicated that the genotype was tolerant to stress. There is a similarity between the above findings and the present study: in LS, the RP\% of all genotype ranged from 61 to $79 \%$ (Fig. 11) Among the 3 varieties, higher RP\% was found in 'BARI Gom-25' (79\%), lowest in 'Gourab' (61\%). Considering the HSI value, 'Gourab' (1.3) was higher than 1.0 in $\mathrm{LS}$, indicating that this genotype had no tolerance to high temperature. The HSI of 'BARI Gom-25' (0.7) and 'BARI Gom-26' (0.9) showed moderate heat stress tolerance (Fig. 11). Among the 3 varieties, 'BARI Gom-25' $(\mathrm{RP} \%=79 ; \mathrm{HSI}=0.7)$ was moderately heat tolerant, followed by 'BARI Gom-26' (RP\% = 74; HSI = 0.9) while 'Gourab' was heat sensitive $(\mathrm{RP} \%=61$; HSI $=1.3)$.

\section{Conclusions}

From the above results and discussion, due to high temperature stress in LS, duration of life cycle stages of our tested wheat varieties was reduced. OS (i.e. optimum sowing on November 15) resulted in better performance of all varieties than late sowing (i.e., LS on December 27). From overall performance (phenology, growth, yield and heat tolerance parameters), 'BARI Gom-25' and 'BARI Gom-26' were considered to be the best performing varieties under heat stress while 'Gourab' was found to be sensitive to heat.

\section{Acknowledgement}

We are most grateful to the staff of the Wheat Research Centre, Bangladesh for maintaining the experimental plants. Financial support from the Director General of the Bangladesh Agricultural Research Institute (BARI) is also gratefully acknowledged.

\section{References}

Acevedo E, Silva P, Silva H (2002). Wheat growth and physiology, 567 p. In: Curtis BC (Ed.). Bread Wheat: Improvement and Production, FAO Plant Production and Protection Series No. 30. Rome, Italy.

Ahamed KU, Nahar K, Fujita M (2010). Sowing date mediated heat stress affects the leaf growth and dry matter partitioning in some spring wheat (Triticum aestivum L.) cultivars. The IIOAB J 1(3):1-9.

Ahmed MF, Ahmed ASH, Burhan HO, Ahmed FE (2003). Effects of sowing date on growth and yield of wheat at different elevations in Jebel Marra highlands under Rain-fed Conditions. Faculty of Agriculture, University of Khartoum, Shambat and Agricultural Research Corporation, Nyala Research Station, Sudan.

Al-Karaki GN (2012). Phenological development-yield relationships in durum wheat cultivars under terminal high temperature stress in semiarid conditions. International Scholarly Research Network. ISRN Agronomy. Article ID 456856, 7 p. Available online: http://www.isrn.com/journals/agronomy/2012/456856/.

Anonymous (2012). Promoting adaptation of climate change in Bangladesh by Practical action Bangladesh. Practicalaction. org/media/download/5857.

Araus J, Ferrio J, Buxo R, Voltas, J (2007). The historical perspective of dry land agriculture: lessons learned from 10000 years of wheat cultivation. J Exp Bot 58(2):131-145. 
Asana RD, Williams RF (1965). The effect of temperature stress on grain development in wheat. Aust J Agril Res 16:1-3.

Bagci SA, Ekiz H, Yilmaz A, Cakmak I (2007). Effects of zinc deficiency and drought on grain yield of field-grown wheat cultivars in Central Anatolia. J Agron Crop Sci 193(3):198206.

Bayramov SM, Babayev HG, Khaligzade MN, Guliyev NM, Raines CA (2010). Effect of water stress on protein content of some Calvin cycle enzymes in different wheat genotypes. Proc ANAS Biol Sci 65(5-6):106-111.

Bogale A, Tesfaye K, Geleto T (2011). Morphological and physiological attributes associated to drought tolerance of Ethiopian durum wheat genotypes under water deficit condition. J Biodiver Environ Sci 1(2):22-36.

Braun HJ, Atlin G, Payne T (2010). Multi-location testing as a tool to identify plant response to global climate change. In: Reynolds CRP (Ed.). Climate change and crop production, CABI, London, UK.

Buriro M, Oad FC, Keerio MI, Tunio S, Gandahi AW, Hassan SWU, Oad SM (2011). Wheat seed germination under the influence of temperature regimes. Sarhad J Agric 27(4):539543.

CCC (Climate Change Cell) (2009). Impact Assessment of Climate Change and Sea Level Rise on Monsoon. Climate Change Cell, Department of Environment, Ministry of Environment and Forest, Dhaka, Bangladesh.

CGIAR (Consultative Group on International Agricultural Research) (2009). CGIAR and Climate Change. Global Climate Change: Can Agriculture Cope? Mapping the Menace of Global Climate Change. CGIAR at COP15-Dec. 2009. Available online at: http://cgiar.bio-mirror.cn/pdf/cc_mappingthemenace.pdf.

Chakrabarti B, Singh SD, Nagarajan S, Aggarwal PK (2011). Impact of temperature on phenology and pollen sterility of wheat varieties. Aust J Crop Sci 5(8):1039-1043.

CIMMYT-ICARDA (2011). WHEAT-Global Alliance for Improving Food Security and the Livelihoods of the Resources-Poor in the Developing World. Proposal submitted by CIMMYT and ICARDA to the CGIAR consortium board, in collaboration with Bioversity, ICRISAT, IFPRI, ILRI, IRRI, IWMI, 86 NARS Institute, 13 Regional and International Organizations, 71 Universities and Advance Research Institutes, 15 Private Sector Organizations, 14 NGOs and Farmers Cooperatives and 20 Host Countries. 197 p. Available online at: www.cimmyt.org/.../503-wheatglobal-alliance-for-improving-food-

Dalirie MS, Sharif RS, Farzaneh S (2010). Evaluation of yield, dry matter accumulation and leaf area index in WGs as affected by terminal drought stress. Not Bot Horti Agrobo 38(1):182-186.

Demirevska K, Simova-Stoilova L, Vassileva V, Vaseva1 I, Grigorova B, Feller U (2008). Drought-induced leaf protein alternations in sensitive and tolerant wheat varieties. Gen Appl Plant Physiol (Special issue) 34(1-2):79-102.
Dias AS, Lidon FC, Ramalho JC (2009). Heat stress in Triticum: Kinetics of $\mathrm{Fe}$ and $\mathrm{Mn}$ accumulation. Braz J Plant Physiol 21(2):153-164.

Din K, Singh RM (2005). Grain filling duration: An important trait in wheat improvement. SAIC Newsletter 15(4):4-5.

Esterling WE, Aggarwal PK, Batima P, Brander KM, Erda L, Howden SM, Kirilenko A, Soussana JF, Schmidhweer J, Tubiello FN (2007). Food, fibre and forest products, 273-313 p. In: Parry ML, Canziani OF, Palutikof JP, Van der Linder PJ, Hanson CE (Eds.). Climate change 2007: Impacts, adaptation and vulnerability. Contribution of working group-11 to the Fourth Assessment Report of the Intergovernmental Panel on Climate Change. Multi-location testing to identify Plant Response 137. Cambridge Univ Press, UK.

El-Fadly GAB, Menshawy AM, Farhat WZE (2007). Molecular and biochemical studies on some bread WGs in relation to water stress tolerance. African Crop Science Conf Proc. Printed by African Crop Science Society, El-Minia, Egypt. 8:605-612.

FAOSTAT (2010). Data, 2007, Food and Agricultural commodities production, Rome, Italy. Available online at: http://faostat.fao.org

Frank AB, Bauer A, Black AL (2009). Effect of air temperature on head development in spring wheat. Great Plains Research Laboratory, USDA-ARS, Mandan, ND, USA. Available online at: http://library.ndsu.edu/tools/dspace/ load/ ?file =/repository/bitstream/handle $/ 10365 / 6154 /$ farm_45_04_04.pdf ?sequence $=1$.

FAO/UNDP (Food and Agricultural Organization/United Nations Development Programme) (1988). Land resources appraisals of Bangladesh for agricultural development. Agroecological regions of Bangladesh. Rome, Report No. 2.

Fischer RA (1985). Number of kernels in wheat crops and the influence of solar radiation and temperature. J Agric Sci 105:447-461.

Fischer RA, Maurer R (1978). Drought resistance in spring wheat cultivars. I. Grain yield responses. Aust J Agric Res 29:897-912.

Foolad MR (2005). Breeding for abiotic stress tolerances in tomato, 613-684 p. In: Ashraf M, Harris PJC (Eds.). Abiotic Stresses: Plant resistance through breeding and molecular approaches, The Haworth Press Inc., NY, USA.

Hakim MA, Hossain A, Teixeira da Silva JA, Zvolinsky VP, Khan MM (2012). Yield, protein and starch content of 20 wheat (Triticum aestivum L.) genotypes exposed to high temperature under late sowing conditions. J Sci Res 4 (2):477-489.

Hall AE (2001). Crop responses to environment. CRC Press LLC, Boca Raton, Florida.

Hasan MA, Ahmed JU (2005). Kernel growth physiology of wheat under late planting heat stress. J National Sci Found Sri Lanka 33(3):193-204.

Hede AR, Skovmand B, Reynolds MP, Crossa J, Vilhelmsen AL, Stolen O (1999). Evaluating genetic diversity for heat 
108 tolerance traits in Mexican wheat landraces. Genet Resour and Crop Evol 46:37-45.

Hellevang KJ (1995). Grain moisture content effects and management. Department of Agricultural and Biosystems Engineering, North Dakota State University. Available online: http://www.ag.ndsu.edu/pubs/plantsci/crops/ae905w.htm

Hossain A, Sarker MAZ, Saifuzzaman M, Akhter MM, Mandal MSN (2009). Effect of sowing dates on yield of wheat varieties and lines developed since 1998. Bangladesh J Prog Sci and Tech $7(1): 5-8$.

Hossain A, Sarker, MAZ, Hakim MA, Lozovskaya MV, Zvolinsky VP (2011). Effect of temperature on yield and some agronomic characters of spring wheat (Triticum aestivum L.) genotypes. Int J Agril Res Innov and Tech 1(1):44-54.

Hossain A, Lozovskaya MV, Zvolinsky VP, Teixeira da Silva JA (2012a). Effect of soil and climatic conditions on yieldrelated components performance of spring wheat (triticum aestivum L.) varieties in northern Bangladesh. Natural Sci: J Fund and Appl Sci 39(2):69-78.

Hossain A, Lozovskaya MV, Zvolinsky VP, Teixeira da Silva JA (2012b). Effect of soil and climatic conditions on phenology of spring wheat varieties in northern Bangladesh. Natural Sci: J Fund and Appl Sci 39(2):78-86.

Hossain A, Teixeira da Silva JA, Lozovskaya MV, Zvolinsky VP (2012c). The Effect of high temperature stress on the phenology, growth and yield of five wheat (Triticum aestivum L.) genotypes. The Asian and Austr J Plant Sci and Biotech 6(1):(in press).

Indexmundi (2011). Bangladesh wheat production by year: Market year, production (1000MT) and growth rate (\%). Available online: http://www.indexmundi.com/agriculture $/$ ?country=bd\&commodity $=$ wheat $\&$ graph $=$ production .

IPCC (2007). Climate Change 2007: Synthesis Report, Contribution of Working Groups I, II and III to the Fourth Assessment Report of the Intergovernmental Panel on Climate Chang [Core Writing Team, Pachauri RK, Reisinger A (Eds.)]. IPCC: Geneva, Switzerland, 104 p.

Islam AS (2009). Analyzing changes of temperature over Bangladesh due to global warming using historic data. Young Scientists of Asia Conclave, Jawaharlal Nehru Centre for Advanced Scientific Research (JNCASR), 15-17 January, Jakkur, Bangalore.

Karmakar S, Shrestha ML (2000). Recent Climatic Changes in Bangladesh. SMRC No.4. SAARC Meteorological Research Centre, Agargaon, Dhaka, Bangladesh.

Karmanenko NM, Osipova LV, Nilovskaya NT (2011). Acid, cold and drought tolerance in cereal. Russ Acad Sci 37:354357.

Khakwani AA, Dennett, MD, Munir M (2011). Drought tolerance screening of wheat varieties by inducing water stress conditions. Songklanakarin J Sci Tech 33:135-142.

Lobell DB, Burke MB, Tebaldi C, Mastrandrea MD, Falcon WP, Naylor RL (2008). Supporting online materials for:
Prioritizing climate change adaptation needs for food security in 2030. Science 319:607-610.

Lukacs A, Partay G, Nemeth T, Csorba S, Farkas C (2008). Drought stress tolerance of two WGs. Soil and Water Res 3(Special Issue 1):95-104.

Modarresi M, Mohammadi V, Zali A, Mardi M (2010). Response of wheat yield and yield related traits to high temperature. Cereal Res Commun 38(1):23-31.

Mahboob AS, Arain MA, Khanzada S, Naqvi MH, Dahot MU, Nizamani NA (2005). Yield and quality parameters of wheat genotypes as affected by sowing dates and high temperature stress. Pak J Bot 37(3):575-584.

Martiniello P, Teixeira da Silva JA (2011). Physiological and bio-agronomical aspects involved in growth and yield components of cultivated forage species in Mediterranean environments: A review. Eu J Plant Sci Biotech 5(Special Issue 2):64-98

Nahar K, Ahamed KU, Fujita M (2010). Phenological variation and its relation with yield in several wheat (Triticum aestivum $\mathrm{L}$.) cultivars under normal and late sown mediated heat stress condition. Not Sci Biol 2(3):51-56

OECD (2003). Rising food prices: Causes and consequences. 9 p. Available online: http://www.oecd.org/ dataoecd/54/42/40847088.pdf.

OECD-FAO (2009). Agricultural outlook 2009-2018. Available online: www.agri-outlook.org.

Poulton PL, Rawson HM (2011). Physical constraints to cropping in southern Bangladesh, 256 p. In: Rawson HM (Ed.) Sustainable Intensification of Rabi Cropping in Southern Bangladesh Using Wheat and Mungbean, ACIAR Technical Reports No. 78. Australian Centre for International Agricultural Research, Canberra.

Rahman MA, Chikushi J, Yoshida S, Karim AJMS (2009). Growth and yield components of wheat genotypes exposed to high temperature stress under control environment. Bangla J Agril Res 34(3):361-372.

Rahman MM, Hossain A, Hakim MA, Kabir MR, Shah MMR (2009). Performance of wheat genotypes under optimum and late sowing condition. Int J Sustain Crop Prod 4(6):3439.

Refay YA (2011). Yield and yield components parameters of bread wheat genotypes as affected by sowing dates. MiddleEast J Sci Res 7(4):484-489.

Rosegrant MW, Agcaoili M (2010). Global food demand, supply, and price prospects to 2010. International Food Policy Research Institute, Washington, DC. USA.

Rosegrant MW, Sombilla MA, Gerpacio RV, Ringler C (1997). Global food markets and US exports in the twenty-first century. Paper prepared for the Illinois World Food and Sustainable Agriculture Program Conference 'Meeting the Demand for Food in the $21^{\text {st }}$ Century: Challenges and Opportunities for Illinois Agriculture, May 27, 1997.

Russell OF (1994). MSTAT-C v.2.1 (A computer based data 
analysis software). Crop and Soil Science Department, Michigan State University, USA.

Shahzad MA, Wasi-ud-Din, Sahi ST, Khan MM, Ehsanullah, Ahmad M (2007). Effect of sowing dates and seed treatment on grain yield and quality of wheat. Pak J Agril Sci 44:581583.

Shirazi MU, Gyamfi JA, Ram T, Bachiri H, Rasyid B, Rehman A, Khan MA, Mujtaba SM, Ali M, Shreen A, Mumtaz S (2010). Selection of some suitable drought tolerant wheat genotypes using carbon isotopes discrimination (CID) technique. Pak J Bot 42(5):3639-3644.

Spiertz JHJ, Vos J (1985). Grain growth of wheat and its limitations by carbohydrate and nitrogen supply, 129-141 p. In: Day W, Atkin RK (Eds.). Wheat growth and modeling, Plenum press, NY.

Spink JH, Clare RW, Kilpatricks JB (1993). Grain quality of milling wheat at different sowing dates. Appl Biol 36:231240.

Tarchoun N, M'hamdi M, Teixeira da Silva JA, Mehouachi T (2012). Approaches to evaluate the sensitivity of hot pepper floral structures to low night temperature. Eu J Hort Sci 77(2):78-83.

Thiry DE, Sears RG, Shroyer JP, Paulsen GM (2002). Keeping up with research: Planting date effect on tiller development and productivity of wheat. Agricultural Experiment Station and Cooperative Extension Service. Available at http:// oznet.ksu.edu.

Timmermans BGH, Vos J, Nieuwburg JV, Stomph TJ, Putten PEL, Molendijk LPG (2007). Field performance of Solanum sisymbriifolium, a trap crop for potato cyst nematodes. I. Dry matter accumulation in relation to sowing time, location, season and plant density. Ann Appl Biol 150:89-97.
109

Ubaidullah, Raziuddin, Mohammad T, Hafeezullah, Ali S, Nassimi AW (2006). Screening of wheat (Triticum aestivum L.) genotypes for some important traits against natural terminal heat stress. Pak J Biol Sci 9:2069-2075.

Ugarte C, Calderini DF, Slafer GA (2007). Grain weight and grain number responsiveness to pre-anthesis temperature in wheat, barley and triticale. Field Crops Res 100(2-3):240248.

Wahid A, Gelani S, Ashraf M, Foolad MR (2007). Heat tolerance in plants: An overview. Environ Exp Bot 61:199-233.

Wardlaw IF (2002). Interaction between drought and chronic high temperature during kernel filling in wheat in a controlled environment. Ann Bot 90:469-476.

Wardlaw IF, Dawson IA, Munibi P, Fewster R (1989a). The tolerance of wheat to high temperature during reproductive growth. I. Survey procedure and general response pattern. Aust J Agric Res 40:1-13.

Wardlaw IF, Dawson IA, Munibi P (1989b). The tolerance of wheat to high temperature during reproductive growth. II. Grain development. Aust J Agric Res 40:15-24.

WRC (Wheat Research Center) (2009), p. 181 In: Annual Report, 2008-09, Wheat Research Center, Nashipur, Dinajpur, Bangladesh.

Zhang B, Li FM, Huang G, Cheng ZY, Zhang Y (2006). Yield performance of spring wheat improved by regulated deficit irrigation in an arid area. Agril Water Manag 79:28-42. 